\title{
The burden of unintended pregnancies in Brazil: a social and public health system cost analysis
}

This article was published in the following Dove Press journal:

International Journal of Women's Health

16 July 2014

Number of times this article has been viewed

\author{
Hoa H Le' \\ Mark P Connolly ${ }^{1,2}$ \\ Luis Bahamondes ${ }^{3}$ \\ Jose G Cecatti ${ }^{3}$ \\ Jingbo $\mathrm{Yu}^{4}$ \\ Henry $X \mathrm{Hu}^{4}$ \\ 'Department of Pharmacoeconomics \\ and Pharmacoepidemiology, University \\ of Groningen, Groningen, the \\ Netherlands; ${ }^{2}$ Global Market Access \\ Solutions, Saint-Prex, Switzerland; \\ ${ }^{3}$ Department of Obstetrics and \\ Gynecology, School of Medical \\ Sciences, University of Campinas, \\ Campinas, Brazil; ${ }^{4}$ Merck \& Co, \\ Whitehouse Station, NJ, USA
}

Correspondence: Mark P Connolly Department of Pharmacoeconomics and Pharmacoepidemiology, University of Groningen, Antonius Deusinglaan I, 97/3 AV Groningen, the Netherlands Tel+3I 503637576 Emailm.connolly@rug.nl; mark@ gmasoln.com
Background: Unintended pregnancy (UP) is an unmet medical need with consequences worldwide. We evaluate the costs of UP based on pregnancies in Brazil from for the year 2010. Methods: The consequences of UP were evaluated using decision analysis based on pregnancy rates and outcomes as miscarriage, induced abortion, and live birth, which were factored into the analysis. The model discriminated between maternal and child outcomes and accounted for costs (in Brazilian currency [Real\$, R\$]) within the Brazilian public health service attributed to preterm birth, neonatal admission, cerebral palsy, and neonatal and maternal mortality. Event probabilities were obtained from local resources.

Results: We estimate that 1.8 million UPs resulted in 159,151 miscarriages, 48,769 induced abortions, 1.58 million live births, and 312 maternal deaths, including ten (3\%) attributed to unsafe abortions. The total estimated costs attributed to UP are R $\$ 4.1$ billion annually, including $\mathrm{R} \$ 32$ million ( $0.8 \%$ ) and $\mathrm{R} \$ 4.07$ billion (99.2\%) attributed to miscarriages and births and complications, respectively. Direct birth costs accounted for approximately $\mathrm{R} \$ 1.22$ billion (30.0\%), with labor and delivery responsible for most costs (R $\$ 988$ million; $24.3 \%$ ) for the year 2010. The remainder of costs were for infant complications ( $\$ 2.84$ billion; 72.3\%) with hospital readmission during the first year accounting for approximately $\mathrm{R} \$ 2.15$ billion $(52.9 \%)$. Based on the national cost, we estimate the cost per UP to be $\mathrm{R} \$ 2,293$.

Conclusion: Despite weaknesses in precise estimates in annual pregnancies and induced abortions, our estimates reflect the costs of UP for different pregnancy outcomes. The main costs associated with UP are in those carried to parturition. The health cost of abortion represents a small proportion of total costs as these are paid for outside of the public health system. Consequently, reductions in UP will generate not only cost savings, but reductions in woman and child morbidity and mortality.

Keywords: unintended pregnancy, public health, Brazil, abortion

\section{Introduction}

The construct of unintended pregnancies (UPs) is multifactorial and broadly encompasses pregnancies that are either unwanted or mistimed. ${ }^{1}$ In many instances, UPs are likely to end by induced abortion; worldwide estimates suggest that $50 \%$ will be voluntarily terminated. ${ }^{2}$ In 2008 , it was estimated that 43.8 million abortions occurred worldwide, of which $86 \%$ occurred in low-/middle-income countries. ${ }^{3}$ Furthermore, between 2003 and 2008, the number of induced abortions was found to have decreased in high-income countries but to have increased in low-/middle-income countries. During this same period of time, the proportion of unsafe abortions increased and they were believed to account for $13 \%$ of maternal deaths, with the majority of these concentrated in countries with restrictive laws on abortion. ${ }^{4}$ 
Elective abortion in Brazil is considered non-legal, unless the pregnancy resulted from a rape, would cause a life-threatening condition to the mother, or the fetus has anencephaly or any other malformation that is incompatible with the extrauterine life. As a result, data on prevalence and associated costs of abortion are limited and remain a challenge to collect. However, it is recognized worldwide that direct health costs of UP and resulting abortions can significantly impact local health services and the families affected. $^{5}$

Health system and societal costs can also arise from UPs that do not end in abortion and are carried to parturition. In the United States, the public health costs attributed to unintended births in a single year cost taxpayers $\$ 11.1$ billion (2006). ${ }^{6}$ Furthermore, previous studies have reported that UPs are more likely to result in preterm births and low-birthweight babies, which would increase health costs for neonatal care and costs associated with long-term disabilities. ${ }^{7}$ This is particularly relevant for UPs in adolescence, which are more likely to result in low-birth-weight births, which can increase health costs. ${ }^{8}$

Over the past few decades, Brazil, like many fastemerging economies, has experienced a fertility transition noted by a dramatic reduction in the total fertility rate, which currently sits at 1.8 births per woman. ${ }^{9,10}$ Furthermore, during the fertility transition, the rate of contraception has also increased. ${ }^{11}$ Despite increased contraception use, the cumulative rate of spontaneous and induced abortion changed very little between 1996 and 2006, for which population survey estimates are available. ${ }^{12,13}$ Furthermore, a survey of more than 1,000 women aged 10-24 years in a single postnatal unit in Brazil reported that more than $50 \%$ of all births were unintended, suggesting that possibly significant unmet contraception need still exists. ${ }^{8}$ Similarly, for the whole country, the data from the last Demographic and Health Survey (DHS) performed in 2006 indicates that $55 \%$ of all births were unintended. ${ }^{14}$

Prevention of UP using publicly funded programs in high-income countries has proven to generate significant cost savings for health services and public services. ${ }^{15}$ Previous economic studies evaluating the consequences of UP have mostly been performed in high-income countries where publicly funded fertility services and abortion legislation are different from those in low-/middle-income countries. ${ }^{15}$ The aim of this study was to evaluate the cost consequences of UP in Brazil, an emerging economy with vastly different fertility planning services than most advanced economies and with restrictive abortion laws. To the best of our knowledge, this is the first published study that describes the economics of UP, and it is believed that this work can aid decision makers regarding access to contraceptives.

\section{Methods Model description}

A model was developed to evaluate the humanistic burden and financial impact of UPs in Brazil. The analysis factored in costs and outcomes for 1 year post-delivery of UPs. Possible birth outcomes of UP included induced abortion, miscarriage, and ongoing pregnancy resulting in birth. All birth deliveries were assumed to have taken place in a hospital within the Brazil public health system as reported by DATASUS, the data system for the Ministry of Health in Brazil. Available data was further separated into vaginal $(61.0 \%)$ and cesarean section (C-section) deliveries (38.4\%). ${ }^{16,17}$ Outcomes and resulting costs for infants were also followed. These included stillbirths and infant survival and complications from term and preterm deliveries. Complications included admission to a neonatal intensive care unit (ICU), hospitalization during the first year, and cerebral palsy. Data from DATASUS were used when possible to populate the model to reflect the reality of the public health care system. However, for parameters not identified in DATASUS, other relevant sources were used. A decision tree model was constructed in Microsoft Excel (Microsoft Corporation, Redmond, WA, USA) from the perspective of the Brazilian public health system (Figure 1). The short-term horizon considered in the analysis precluded the need for discounting.

\section{Data source and analysis}

The total annual number of pregnancies was estimated using the reported number of live births for the year 2010 and adjusted with estimated percentages of induced abortion and miscarriage. ${ }^{18}$ The percentages of induced abortions and miscarriage were derived from the population-based 2006 DHS and found to be $1.5 \%$ and $8.9 \%$, respectively. ${ }^{19}$ All induced abortions in the model were assumed to be from unintended pregnancies resulting in an adjusted abortion rate of $2.7 \%$. The UP rate was estimated to represent $55 \%$ of all pregnancies. ${ }^{20}$

Maternal mortality rates of 20 , ten, and 30 deaths per 100,000 births were used for miscarriage, vaginal delivery, and C-section delivery, respectively. ${ }^{21-23}$ In addition, a case fatality rate of 100 deaths per 100,000 abortions was assumed. ${ }^{24}$ For both delivery methods, it was estimated that $7.8 \%$ of all deliveries were preterm births and $0.85 \%$ were stillbirths. ${ }^{25}$ The remainder of the deliveries was assumed to 


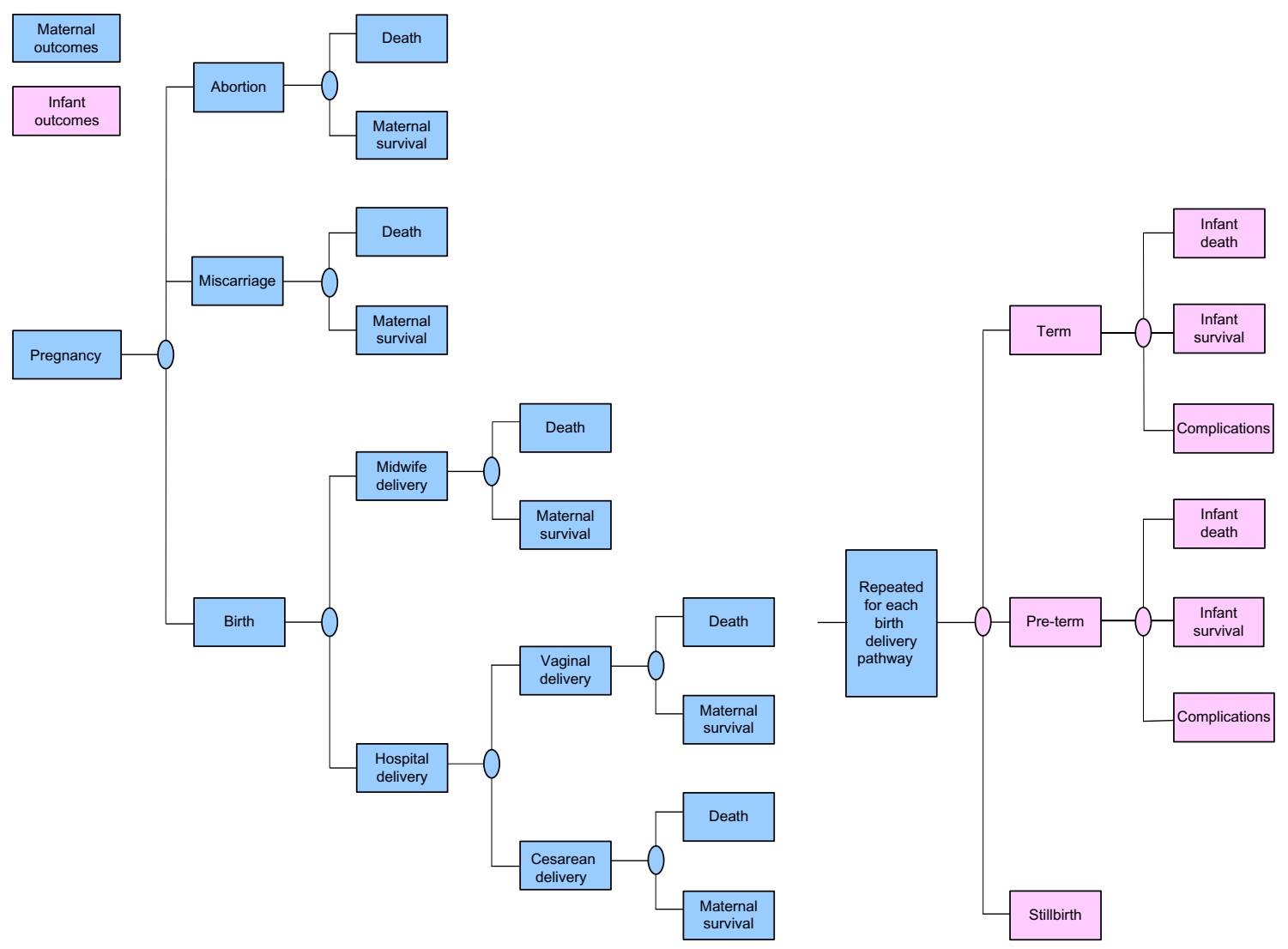

Figure I Unintended pregnancy decision model depicting the three main pregnancy outcomes.

be term births. Differential infant mortality rates were used for term and preterm births, with 8.5 per 1,000 live births for the former and 68 per 1,000 live births for the latter. ${ }^{25,26}$ The model assessed infant complications, including admissions to neonatal ICU, hospitalization during the first year, and cerebral palsy. All preterm birth infants were assumed to require neonatal intensive care, compared to $7.6 \%$ of term birth infants. ${ }^{27}$ For preterm infants, the average number of hospitalizations during the first year was 1.7 , mostly from respiratory issues. ${ }^{28}$ For term birth infants, hospitalization was calculated as a relative risk reduction. ${ }^{29}$ Cerebral palsy occurred in $0.1 \%$ and $1.7 \%$ of term and preterm births, respectively. ${ }^{30}$

\section{Cost resources}

Resource use and unit costs were identified from published sources and the DHS in Brazil. In Brazil the public national health system (SUS) pays for around $70 \%-75 \%$ of all reproductive procedures. However, in this model, it is assumed that the costs are those from the public system, although, in approximately one-quarter of UPs, the costs are probably higher when related to women's care covered by insurance or privately.
Costs of elective abortion were not included in the analysis because these procedures rarely meet the legal requirements and would not be covered by the public health system. Costs of miscarriage were related to the following procedures: pelvic exam, blood test, ultrasound, and dilation and curettage. Separate vaginal and $\mathrm{C}$-section delivery costs were used. The cost components for each method included antenatal care and labor and delivery. ${ }^{31,32}$ Unit cost for hospitalization readmission during the first year was $\mathrm{R} \$ 2,794 .{ }^{33}$ This unit cost was also assumed for neonatal care admission, while cerebral palsy was estimated to be $\mathrm{R} \$ 19,854 .{ }^{33}$ Cost parameters are summarized in Table 1.

\section{Results}

Based on the modeled parameters we estimate 1.79 million annual UPs and 1.47 million annual planned pregnancies. We estimate annual maternal deaths of 351, of which 49 (14\%) are attributed to abortions and 302 to complications from miscarriages and deliveries. The number of infant deaths within the 12 months following birth was estimated at 32,864 . The model estimates preterm deliveries attributed to UP as 122,523 . The number of estimated neonatal 
Table I Cost variables included in the economic model

\begin{tabular}{lll}
\hline Outcomes & Costs $^{\mathbf{a}}$ & Reference \\
\hline Abortion & $\mathrm{R} \$ 0$ & \\
Miscarriage & $\mathrm{R} \$ 206.8 \mathrm{I}$ & 34 \\
$\begin{array}{l}\text { Birth } \\
\quad \text { Vaginal delivery }\end{array}$ & \\
$\quad$ Antenatal care & $\mathrm{R} \$ 152.74$ & $3 \mathrm{I}$ \\
$\quad$ Labor and delivery & $\mathrm{R} \$ 562.82$ & 32 \\
$\quad$ Cesarean delivery & & \\
$\quad$ Antenatal care & $\mathrm{R} \$ 152.74$ & $3 \mathrm{I}$ \\
$\quad$ Labor and delivery & $\mathrm{R} \$ 784.90$ & 32 \\
$\quad$ Infant complications & & \\
$\quad$ Neonatal care & $\mathrm{R} \$ 2,793.92$ & 33 \\
$\quad$ Infant hospitalization during & $\mathrm{R} \$ 2,793.92$ & 33 \\
$\quad$ first year & & \\
$\quad$ Cerebral palsy & $\mathrm{R} \$ 19,853.94$ & 33 \\
\hline
\end{tabular}

Note: aExchange rate: US\$I = almost $R \$ 2$.

admissions for the year 2010 associated with UP was 224,631 which included all preterm deliveries and $7.6 \%$ of all term deliveries. The disaggregated values for different pregnancy outcomes attributed to UP are described in Table 2.

The direct costs associated with UP are categorized by miscarriages and births. Costs are disaggregated to relevant cost components (Table 3). Costs of abortions are not reimbursed in the public health system and are not included in the analysis. The total costs attributed to UP are estimated to be $\mathrm{R} \$ 4.1$ billion annually, of which approximately $\mathrm{R} \$ 32.9$ million $(0.8 \%)$ was attributed to miscarriage and $\mathrm{R} \$ 4.07$ billion (99.2\%) to births and resulting complications.

Table 2 Annual unintended pregnancy outcomes in Brazil

\begin{tabular}{lc}
\hline Pregnancy outcomes & Number of cases \\
\hline Unintended pregnancies & $1,788,212$ \\
Live births & $1,580,292$ \\
Miscarriages & $159,15 \mathrm{I}$ \\
Induced abortions & 48,769 \\
Planned pregnancies & $1,463,083$ \\
Live births & $1,332,868$ \\
Miscarriages & 130,214 \\
Delivery type & \\
Vaginal births & 935,059 \\
Cesarean births & 588,627 \\
Infant complications & \\
Preterm deliveries & 122,523 \\
Neonatal care admission & $224,63 \mathrm{I}$ \\
Hospital readmissions within year after birth & 769,477 \\
Cerebral palsy cases & 3,448 \\
Total maternal deaths & 351 \\
Unsafe abortion & 49 \\
Miscarriage & 32 \\
Birth & 270 \\
Infant deaths within the first year & 32,864 \\
(includes neonatal period) & \\
\hline
\end{tabular}

Table 3 Annual costs of unintended pregnancy in Brazil based on different pregnancy outcomes

\begin{tabular}{|c|c|c|}
\hline Pregnancy outcomes & Annual cost ${ }^{a}$ & $\begin{array}{l}\text { Percentage of } \\
\text { annual costs }\end{array}$ \\
\hline Miscarriage costs & $\mathrm{R} \$ 32,9 \mid 3,992$ & $0.8 \%$ (of total) \\
\hline Birth costs & $\mathrm{R} \$ 4,066,926,567$ & $99.2 \%$ (of total) \\
\hline Birth delivery-related costs & $\mathrm{R} \$ \mathrm{I}, 22 \mathrm{I}, 0 \mathrm{I} 0,848$ & $30.0 \%^{\mathrm{b}}$ \\
\hline Antenatal care & $\mathrm{R} \$ 232,727,755$ & $5.7 \%$ \\
\hline Labor and delivery & $R \$ 988,283,092$ & $24.3 \%$ \\
\hline Infant complications & $\mathrm{R} \$ 2,845,915,7 \mid 9$ & $70.0 \%$ \\
\hline Neonatal care admission & $\mathrm{R} \$ 627,60 \mathrm{I}, 523$ & $15.4 \%$ \\
\hline $\begin{array}{l}\text { Hospital readmission in } \\
\text { Ist year }\end{array}$ & $R \$ 2,149,858,847$ & $52.9 \%$ \\
\hline Cerebral palsy & $\mathrm{R} \$ 68,455,349$ & $1.7 \%$ \\
\hline $\begin{array}{l}\text { Sum all costs annual } \\
\text { unintended pregnancies }\end{array}$ & $\mathrm{R} \$ 4,099,840,559$ & $100 \%$ \\
\hline
\end{tabular}

Notes: ${ }^{\mathrm{a} E x c h a n g e}$ rate: $U S \$ 1=$ almost $\mathrm{R} \$ 2$; ${ }^{\text {p}}$ ercentage of subcategory for abortion, miscarriage, and birth costs.

From the direct birth-related costs, antenatal care accounted for approximately $\mathrm{R} \$ 233$ million (5.7\%) of birth costs, with labor and delivery costs responsible for R $\$ 988$ million (24.3\%). The remainder of birth costs were attributed to infant complications, estimated to be R $\$ 2.8$ billion (70.0\%), with neonatal costs accountable for approximately $\mathrm{R} \$ 628$ million $(15.4 \%)$ and hospital readmission in the first year costs of $\mathrm{R} \$ 2.1$ billion (52.9\%) of all birth costs annually. Based on the national cost estimates and the number of annual UPs, we estimate the cost per UP to be R $\$ 2,293$.

\section{Discussion}

Our analysis estimates the costs and outcomes associated with unintended pregnancies to derive a cost per UP of $\mathrm{R} \$ 2,293$. The cost per UP factors in a range of health-related costs attributed to those resulting in abortion and resulting live births for those carried to parturition. This figure is broadly aligned with previous analyses in the United States of $\$ 1,609$ per UP after factoring in the purchasing power parity between the two countries. ${ }^{35}$ It is also worth noting that the estimates provided here are likely an underestimate of all costs. For example, the analysis described here focused on the costs that occur within the public health systems. Consequently, costs of elective abortions paid for by individuals are not represented in this analysis. Furthermore, because elective abortion is illegal in Brazil except in extreme and rare cases, hidden costs from elective abortions may filter into the public health system. For instance, costs associated with post-abortive care are likely to be classified as miscarriages when reported to national authorities. Additionally, the longterm societal costs that arise from UP and reduced educational attainment and lost productivity of young mothers has not been accounted for in our analysis. ${ }^{36-39}$ 
Our analysis highlights that considerable cost savings can be achieved by reducing UP, which are thought to represent $55 \%$ of all pregnancies in Brazil. ${ }^{20}$ The analysis accounted for both untimed and unwanted births to estimate the UP rate and associated costs, in which live births resulting from unwanted pregnancies represented the largest share of health costs, representing $99 \%$ of all costs. This is also attributed to the fact that abortion is a relatively inexpensive procedure that is paid for outside of the health service. Because a substantial proportion of pregnancies are attributed to mistimed pregnancies, ie, pregnancies that would have occurred at some point in the future, but occurred sooner due to mistimed pregnancy, the actual cost savings to be realized by reducing UP is less than described here and would mostly be associated with averting those pregnancies considered to be unwanted. To put the potential cost savings into perspective, an analysis conducted for the state of California, USA estimated that preventing many UP in a single year will offer savings of $\$ 1.1$ billion up to 2 years of age of the child, and that every dollar spent on averting UP offers $\$ 2.76$ of saving in 2 years and $\$ 5.33$ at 5 years post-delivery. ${ }^{15} \mathrm{~A}$ national-level analysis that focused on the federally financed Medicaid program in the United States noted that taxpayer savings of \$4.7-\$6.2 billion could be achieved by reducing unintended pregnancies. ${ }^{40}$ Based on the cost savings attributed to UP, it is anticipated that future health researchers can build on the research described here to better understand the cost savings that may be achieved through improved contraceptive use.

The analysis sought to incorporate a broad range of costs associated with UP to illustrate that costs extend beyond the point of delivery. For instance, UPs often occur in adolescent and young adults and can be predictive of low birth weight, preterm birth, and neonatal admission. ${ }^{8,41-43}$ The precise mechanism by which UP influences preterm birth is likely to be multifactorial. However, some studies have observed that women with UPs are less likely to receive adequate prenatal care ${ }^{44}$ and are also more likely to smoke and drink alcohol during pregnancy, which contributes to adverse outcomes. ${ }^{44,45}$ It is important to highlight these costs because it suggests that UPs place unnecessary demand on health services that are often stretched to capacity. Since UP, for the most part, can be avoided, this illustrates the health service benefits and health service capacity that could be released by reducing UP.

Much of the humanistic burden attributed to UP relates to maternal mortality and morbidity of women who pursue unsafe abortions. In our analysis, we estimate 49 annual deaths from abortions representing $13 \%$ of the estimated maternal deaths. It has been suggested that access to improved contraceptive services could prevent maternal mortality by $25 \%-35 \%{ }^{46}$ Furthermore, estimates from the World Health Organization reported that unsafe abortion disables approximately 5 million women each year, suggesting reductions in morbidity could also be achieved through improved contraception use. ${ }^{4}$

Empirical evidence and clinical guidelines agree that the most effective approach to preventing UP is through education and contraceptive use, of which long-acting contraceptive (LARC) methods are the most effective intervention. ${ }^{47-51}$ In particular, among adolescents, prevailing evidence suggests that education and contraception are the main interventions for reducing UP. ${ }^{49}$

In advanced economies, the percentage of women using LARC methods has been steadily increasing. A recent study noted that the proportion of women using LARC methods has increased from $2.4 \%$ of women aged $15-44$ years since 2002 to $8.5 \%$ of women in $2009 .{ }^{52}$ In the United States, the American College of Obstetricians and Gynecologists (ACOG) advocates use of intrauterine contraceptives (both copper-intrauterine device and the levonorgestrel-releasing intrauterine system) and implants as first-line therapy for adolescent women because they contribute to reduce the number of UPs. ${ }^{48}$ LARC has also proven to be cost-saving compared with combined oral contraceptives in the United Kingdom. Investigators reported that this finding was influenced almost entirely by the lower failure rates associated with LARC. ${ }^{50,53}$ An analysis conducted in the United States also noted that cost savings could be achieved by switching women from oral contraceptives to LARCs, and approximately $50 \%$ of costs of UP were attributed to contraceptive adherence. ${ }^{54}$

Despite the positive benefits of LARC, use in Brazil lags behind that of other countries. A survey conducted in 2008 in Northern Brazil reported that only $1 \%$ of women attending a post-abortion clinic elected for an intrauterine device, despite $93 \%$ of women having knowledge of the product. ${ }^{55}$ Several barriers have been identified, which often limit uptake of LARC methods. ${ }^{56}$ These include health care provider lack of knowledge of risks, myths, misconceptions, and lack of training for insertion of the various devices. Also, misinformation and fear of pain at insertion among women can limit demand for LARC methods. Furthermore, LARC can often involve considerable up-front expense, although evidence does suggest that these methods are cost-effective compared with alternative contraceptive methods. Because of the expense, reimbursement can influence the rate of uptake.

Even recognizing the importance of abortion, and especially induced and unsafe abortion, for maternal mortality 
and morbidity in Brazil, there are no reliable and available data confirming a pandemic of such conditions as commonly reported by media and gray literature. Data extracted from the 2006 Brazilian DHS indicated that only 1.5\% self-reported induced abortions among all pregnancies for the whole period of the survey. ${ }^{14,19}$ A probable contribution for this scenario is the high prevalence of and easy access to contraceptive use among women in reproductive age in the country during the last 2 decades. Although all induced abortions are technically classified as unsafe, this is not the impression of the majority of obstetricians working in the field. There is a general belief that complications due to unsafe induced abortions are less and less frequent and that there was recently a marked drop in their occurrence. With no direct information to confirm this, one indirect point of evidence is the decrease in the proportional contribution of abortion as cause of maternal mortality in the country. In fact, official Brazilian data confirm that it was $16.4 \%$ in 1990 (representing the third cause of maternal mortality), while only $8.9 \%$ in 2000 and $9.0 \%$ in 2010 (the fifth cause, behind even the indirect obstetric causes). ${ }^{20}$ In the meantime, there was a spread of the use of misoprostol as an agent for inducing abortion, not only in health facilities for situations where abortion is allowed, but mainly for situations not legally permitted, wherein the women obtain misoprostol in the black market and self-administer it vaginally. This is believed to be the current most common way of inducing medical abortion and also to be associated with the low rates of severe complications due to abortion, especially infection and hemorrhage, in Brazil.

There are also at least two possible limitations for the external validity of the current cost estimates. The first refers to the assumption that all miscarriages are really diagnosed and "treated" with dilation and curettage. However, it is possible that a proportion of individuals will never reach health facilities and receive no intervention. The second refers to another assumption that all medical abortions are unsafe. Currently, in Brazil, the majority of medical abortions are performed by the woman through self-administration of misoprostol acquired off-label or in the black market. With these procedures, the rate of complications due to medical abortions has dropped significantly during the last decade, with some of these cases arriving at hospitals already as complete abortions that need no complementary procedures. Although insufficient data are available to support this scenario, this would probably impact strongly on the estimates of post-abortion care, taking into account the correspondent reduced morbidity and mortality.

The cost consequences of live births attributed to UP in adolescents can extend beyond the observed costs of increased prenatal care, preterm births, and abortions. Studies have noted that adolescent women are more likely to dropout from school following pregnancy. Furthermore, others have suggested that future generations will follow the reproductive pattern of their parents, which could perpetuate the likelihood of UP in the offspring of these mothers. ${ }^{57}$ As reported, education has been shown to break the association of adolescent fertility across generations, suggesting the longer-term benefits to be achieved by reducing UP.

\section{Conclusion}

Our analysis illustrates the cost consequences associated with UP in Brazil. In the past 2 decades, Brazil has made considerable progress toward reducing abortion rates, but, despite these efforts, the humanistic and direct economic costs associated with UP remain high. ${ }^{58}$ To achieve economic savings from reducing the UP rate will require education, training of providers, and improved access to effective contraceptive measures. It is believed that the research described herein can inform the burden of UP and the benefits of improved fertility planning.

\section{Implications}

The cost consequences associated with UP in Brazil could be investigated in other settings using the same methodology used in this report. It is important to estimate the cost associated to UP to initiate actions to reduce the high rate observed in many countries.

\section{Disclosure}

The research conducted by Dr Hoa H Le and Dr Mark P Connolly was funded by an unrestricted grant from Merck. Dr Jingbo Yu is an employee of Merck, and Dr Henry X Hu is a former employee of Merck. Professors Luis Bahamondes and Jose G Cecatti received a stipend to cover costs in relation to their contributions to the manuscript. Dr Hoa H Le and Dr Mark P Connolly declare no conflicts of interest regarding the publication of this article, and specifically no financial interests in the commercial operations of Merck. The authors report no other conflicts of interest in this work.

\section{References}

1. Santelli J, Rochat R, Hatfield-Timajchy K, et al; Unintended Pregnancy Working Group. The measurement and meaning of unintended pregnancy. Perspect Sex Reprod Health. 2003;35(2):94-101.

2. Gipson JD, Koenig MA, Hindin MJ. The effects of unintended pregnancy on infant, child, and parental health: a review of the literature. Stud Fam Plann. 2008;39(1):18-38.

3. Sedgh G, Singh S, Shah IH, Ahman E, Henshaw SK, Bankole A. Induced abortion: incidence and trends worldwide from 1995 to 2008. Lancet. 2012;379(9816):625-632. 
4. Unsafe Abortion: Global and Regional Estimates of the Incidence of Unsafe Abortion and Associated Mortality in 2008. 6th ed. Geneva: World Health Organization; 2011. Available from: http://whqlibdoc.who.int/ publications/2011/9789241501118_eng.pdf. Accessed July 18, 2012.

5. Vlassoff M, Walker D, Shearer J, Newlands D, Singh S. Estimates of health care system costs of unsafe abortion in Africa and Latin America. Int Perspect Sex Reprod Health. 2009;35(3):114-121.

6. Sonfield A, Kost K, Gold RB, Finer LB. The public costs of births resulting from unintended pregnancies: national and state-level estimates. Perspect Sex Reprod Health. 2011;43(2):94-102.

7. Born Too Soon: The Global Action Report on Preterm Birth. Geneva: World Health Organization; 2012. Available from: http://www.who. int/pmnch/media/news/2012/introduction.pdf. Accessed September 17, 2012.

8. Rocha RC, de Souza E, Soares EP, Nogueira ES, Chambô Filho A, Guazzelli CA. Prematurity and low birth weight among Brazilian adolescents and young adults. J Pediatr Adolesc Gynecol. 2010;23(3): $142-145$.

9. Fertility rate, total (births per woman) [webpage on the Internet]. Washington, DC: The World Bank; 2010. Available from: http://data. worldbank.org/indicator/SP.DYN.TFRT.IN. Accessed July 24, 2012.

10. Potter JE, Schmertmann CP, Assunção RM, Cavenaghi SM. Mapping the timing, pace, and scale of the fertility transition in Brazil. Popul Dev Rev. 2010;36(2):283-307.

11. Curtis SL. Contraceptive use dynamics research needs post fertility transition. Rev Bras Estud Popul. 2012;29(1):191-193.

12. Camargo RS, Santana DS, Cecatti JG, et al. Severe maternal morbidity and factors associated with the occurrence of abortion in Brazil. Int $J$ Gynaecol Obstet. 2011;112(2):88-92.

13. Cecatti JG, Guerra GV, Sousa MH, Menezes GM. [Abortion in Brazil: a demographic approach]. Rev Bras Ginecol Obstet. 2010;32:105-111. Portuguese.

14. Tabela de taxas e diárias 2013 [Table of fees and daily rates 2013]. Ministry of Health of Brazil; 2011. Available from: http://www. justicaeleitoral.jus.br/arquivos/tre-df-tabela-de-taxas-e-diarias-2011/ view? searchterm $=$ Tabela $\% 20 \mathrm{de} \% 20$ taxas $\% 20 \mathrm{e} \% 20 \mathrm{di} \% \mathrm{C} 3 \% \mathrm{~A} 1$ rias. Accessed April 25, 2012. Portuguese.

15. Amaral G, Foster DG, Biggs MA, Jasik CB, Judd S, Brindis CD. Public savings from the prevention of unintended pregnancy: a cost analysis of family planning services in California. Health Serv Res. 2007;42(5): 1960-1980.

16. Unique health system hospital information system (SIH/SUS). Quantity of deliveries in 2012. 03.10.01.003-9 vaginal delivery; 03.10.01.004-7 high-risk pregnancy vaginal delivery [webpage on the Internet]. Ministry of Health of Brazil. Available from: http:// www2.datasus.gov.br/DATASUS/index.php?area=0202. Accessed February 18, 2013. Portuguese.

17. Unique health system hospital information system (SIH/SUS). Quantity of deliveries in 2012. 04.11.01.002-6 high-risk pregnancy cesarean delivery; 04.11.01.003-4 cesarean delivery; 04.11.01.004-2 cesarean delivery with tubal ligation [webpage on the Internet]. Ministry of Health of Brazil. Available from: http://www2.datasus.gov.br/DATASUS/index. php?area $=0202$. Accessed February 18, 2013. Portuguese.

18. Estatísticas do Registro Civil [Civil Registry Statistics]. Brazil Institute of Statistics; 2010. Available from: http://www.ibge.gov.br/home/estatistica/populacao/registrocivil/2010/tabelas_pdf/tabela1_1.pdf. Accessed September 12, 2012. Portuguese.

19. Pesquisa Nacional de Demografia e Saúde da Criança e da Mulher: Banco de dados [National Demographic and Health of Children and Women: Database] [webpage on the Internet]. Ministry of Health of Brazil; 2008. Available from: http://bvsms.saude.gov.br/bvs/pnds/ banco_dados.php. Accessed October 12, 2012. Portuguese.

20. Pesquisa revela dados sobre parto e nascimento no Brasil [Research reveals data on labor and delivery in Brazil] [webpage on the Internet]. Ministry of Health of Brazil; 2012. Available from: http://www.ensp. fiocruz.br/portal-ensp/informe/site/materia/detalhe/29584. Accessed February 12, 2014. Portuguese.
21. Óbitos de mulheres em idade fértil e óbitos maternos - Brasil [Deaths of women in fertile age and maternal deaths - Brazil. Ministry of Health of Brazil] [webpage on the Internet]. Unique Health system hospital information system (SIH/SUS). Ministry of Health of Brazil. Accessed June 26, 2014. Portuguese.

22. Unique Health system hospital information system (SIH/SUS). Quantity of deaths during procedure hospitalization in 2012. 03.10.01.003-9 vaginal delivery; $03.10 .01 .004-7$ high-risk pregnancy vaginal delivery. Ministry of Health of Brazil. Available from: http://www2.datasus.gov. br/DATASUS/index.php?area=0202. Accessed February 18, 2013. Portuguese.

23. Unique Health system hospital information system (SIH/SUS). Quantity of deaths during procedure hospitalization in 2012. 04.11.01.002-6 highrisk pregnancy cesarean delivery; 04.11.01.003-4 cesarean delivery; 04.11.01.004-2 cesarean delivery with tubal ligation. Ministry of Health of Brazil. Available from: http://www2.datasus.gov.br/DATASUS/index. php?area $=0202$. Accessed February 18, 2013. Portuguese.

24. Grimes DA, Benson J, Singh S, et al. Unsafe abortion: the preventable pandemic. Lancet. 2006;368(9550):1908-1919.

25. Live Births information system - (SINASC). Neonatal mortality rate0 to 6 days of life. Total statistics - not split by type of delivery or child health condition. Ministry of Health of Brazil. Available from: http:// www2.datasus.gov.br/DATASUS/index.php?area=0202. Accessed February 12, 2013. Portuguese.

26. Santos IS, Menezes AM, Mota DM, et al. Infant mortality in three population-based cohorts in Southern Brazil: trends and differentials. Cad Saude Publica. 2008;24 Supp1 3:S451-S460.

27. Tracy SK, Tracy MB, Sullivan E. Admission of term infants to neonatal intensive care: a population-based study. Birth. 2007;34(4):301-307.

28. Freitas M, Siqueira A, Segre CA. Follow-up evaluation of children with birth weight less than or equal to 2,000 g. Sao Paulo Med J. 2004;122(6): 239-245.

29. Riccetto AG, Ribeiro JD, Silva MT, et al. Respiratory syncytial virus (RSV) in infants hospitalized for acute lower respiratory tract disease: incidence and associated risks. Braz J Infect Dis. 2006;10(5):357-361.

30. Moster D, Lie RT, Markestad T. Long-term medical and social consequences of preterm birth. N Engl J Med. 2008;359(3):262-273.

31. Antenatal and qualified and attention puerperium humanized manual; 2006. Procedures considered for calculation. 03.01.01.006-4 - Medical consultation. 02.02.02.038-0 - CBC; 02.02.01.007-4 classic glycemic curve determination; 02.02.03.117-9 syphilis detection in pregnant woman; 02.02.05.001-7 analysis of physical characters, and elements of urine sediment; 02.02.03.004-0 HIV-1 RNA detection (Qualitative); 02.02.03.063-6 antibodies against the surface antigen of hepatitis B virus (anti-HBs); 02.02.03.087-3 toxoplasma IgM antibodies. Ministry of Health of Brazil. Available from: http://portal.saude.gov.br/portal/ arquivos/pdf/manual_puerperio_2006.pdf; Accessed February 18, 2013. Portuguese.

32. Antenatal and delivery costs: Unique Health system hospital information system (SIH/SUS). Ministry of Health of Brazil. Available from: http://www2.datasus.gov.br/DATASUS/index.php?area=0202. Accessed September 18, 2013. Portuguese.

33. Morbidade hospitalar do SUS - por local de internação - BRASIL [Hospital morbidity of SUS - by local hospital - Brazil] [webpage on the Internet]. Unique health system hospital information system (SIH/ SUS). Ministry of Health of Brazil. Available from: http://tabnet.datasus. gov.br/cgi/tabcgi.exe?sih/cnv/niuf.def. Accessed February 18, 2013. Portuguese.

34. Miscarriage rate: Unique health system hospital information system (SIH/SUS). Ministry of Health of Brazil. Labor and delivery costs. Available from: http://www2.datasus.gov.br/DATASUS/index. php?area $=0202$. Accessed February 12, 2013. Portuguese.

35. Trussell J. The cost of unintended pregnancy in the United States. Contraception. 2007;75(3):168-170.

36. Jones AS, Astone NM, Keyl PM, Kim YJ, Alexander CS. Teen childbearing and educational attainment: a comparison of methods. J Fam Econ Issues. 1999;20(4):387-418. 
37. Bailey PE, Bruno ZV, Bezerra MF, Queiróz I, Oliveira CM, Chen-Mok M. Adolescent pregnancy 1 year later: the effects of abortion vs motherhood in Northeast Brazil. JAdolesc Health. 2001;29(3): 223-232.

38. Schwarz EB, Smith R, Steinauer J, Reeves MF, Caughey AB. Measuring the effects of unintended pregnancy on women's quality of life. Contraception. 2008;78(3):204-210.

39. Institute of Medicine (US) Committee on Understanding Premature Birth and Assuring Healthy Outcomes; Behrman RE, Butler AS, editors. Preterm Birth: Causes, Consequences, and Prevention. Washington, DC: National Academies Press; 2007

40. Monea E, Thomas A. Unintended pregnancy and taxpayer spending. Perspect Sex Reprod Health. 2011;43(2):88-93.

41. Shah PS, Balkhair T, Ohlsson A, Beyene J, Scott F, Frick C. Intention to become pregnant and low birth weight and preterm birth: a systematic review. Matern Child Health J. 2011;15(2):205-216.

42. Oliveira EF, Gama SG, Silva CM. [Teenage pregnancy and other risk factors for fetal and infant mortality in the city of Rio de Janeiro, Brazil]. Cad Saude Publica. 2010;26(3):567-578. Portuguese.

43. Chen XK, Wen SW, Fleming N, Demissie K, Rhoads GG, Walker M. Teenage pregnancy and adverse birth outcomes: a large population based retrospective cohort study. Int J Epidemiol. 2007;36(2):368-373.

44. Bassani DG, Surkan PJ, Olinto MT. Inadequate use of prenatal services among Brazilian women: the role of maternal characteristics. Int Perspect Sex Reprod Health. 2009;35(1):15-20.

45. Mohllajee AP, Curtis KM, Morrow B, Marchbanks PA. Pregnancy intention and its relationship to birth and maternal outcomes. Obstet Gynecol. 2007;109(3):678-686.

46. Lule E, Singh S, Chowdhury SA. Fertility Regulation Behavior and Their Costs: Contraception and Unintended Pregnancies in Africa and Eastern Europe and Central Asia. Washington, DC: The World Bank; 2007. Available from: http://siteresources.worldbank.org/ HEALTHNUTRITIONANDPOPULATION/Resources/2816271095698140167/FertilityRegulationsFinal.pdf. Accessed June 26, 2014.

47. American College of Obstetricians and Gynecologists. ACOG Committee Opinion No 392, December 2007. Intrauterine device and adolescents. Obstet Gynecol. 2007;110(6):1493-1495.
48. American College of Obstetricians and Gynecologists Committee on Gynecologic Practice; Long-Acting Reversible Contraception Working Group. ACOG Committee Opinion no 450: increasing use of contraceptive implants and intrauterine devices to reduce unintended pregnancy. Obstet Gynecol. 2009;114(6):1494-1498.

49. Oringanje C, Meremikwu MM, Eko H, Esu E, Meremikwu A, Ehiri JE. Interventions for preventing unintended pregnancies among adolescents. Cochrane Database Syst Rev. 2009;(4):CD005215.

50. Winner B, Peipert JF, Zhao Q, et al. Effectiveness of long-acting reversible contraception. N Engl J Med. 2012;366:1998-2007.

51. Facts on Abortion in Latin America and the Caribbean. New York, NY: Guttmacher Institute; 2012. Available from: http://www.guttmacher.org/ pubs/IB_AWW-Latin-America.pdf. Accessed February 18, 2013.

52. Finer LB, Jerman J, Kavanaugh ML. Changes in use of long-acting contraceptive methods in the United States, 2007-2009. Fertil Steril. 2012;98(4):893-897.

53. Mavranezouli I; LARC Guideline Development Group. The costeffectiveness of long-acting reversible contraceptive methods in the UK: analysis based on a decision-analytic model developed for a National Institute for Health and Clinical Excellence (NICE) clinical practice guideline. Hum Reprod. 2008;23(6):1338-1345.

54. Trussell J, Henry N, Hassan F, Prezioso A, Law A, Filonenko A. Burden of unintended pregnancy in the United States: potential savings with increased use of long-acting reversible contraception. Contraception. 2013;87(2):154-161.

55. Ferreira AL, Souza AI, Lima RA, Braga C. Choices on contraceptive methods in post-abortion family planning clinic in the northeast Brazil. Reprod Health. 2010;7:5.

56. Speidel JJ, Harper CC, Shields WC. The potential of longacting reversible contraception to decrease unintended pregnancy. Contraception. 2008;78(3):197-200.

57. de Almeida Mda C, Aquino EM. The role of education level in the intergenerational pattern of adolescent pregnancy in Brazil. Int Perspect Sex Reprod Health. 2009;35(3):139-146.

58. Singh S, Sedgh G, Hussain R. Unintended pregnancy: worldwide levels, trends, and outcomes. Stud Fam Plann. 2010;41(4):241-250.
International Journal of Women's Health

\section{Publish your work in this journal}

The International Journal of Women's Health is an international, peerreviewed open-access journal publishing original research, reports, editorials, reviews and commentaries on all aspects of women's healthcare including gynecology, obstetrics, and breast cancer. The manuscript management system is completely online and includes

\section{Dovepress}

a very quick and fair peer-review system, which is all easy to use. Visit http://www.dovepress.com/testimonials.php to read real quotes from published authors. 